\title{
Development and Performance Evaluation of a Motorized Fish Smoking Kiln
}

\section{Ashaolu Michael O*}

Agricultural and Bio-Environmental Engineering Department, Lagos State Polytechnic, Ikorodu Lagos, Nigeria

\begin{abstract}
Fish smoking is a major activity in the fish industry. In most riverside areas in Nigeria, where fish business is very prominent smoking operations are mostly carried out manually and under unhygienic conditions. The concept of the smoking kiln development is to ease the drudgery associated with traditional methods (drum smoking) in the riverside communities. In this study, a motorized fish smoking kiln was designed, fabricated with locally available materials. The smoking process is based on natural convection of heated air with temperature ranging between $60^{\circ} \mathrm{C}$ and $110^{\circ} \mathrm{C}$. The fish smoking kiln has an overall dimension of $1600 \times 1220 \times 70 \mathrm{~mm}$ and uses charcoal as the main source of energy. The average capacity of the smoking chamber is $120 \mathrm{~kg}$. The performance test was conducted to ascertain its performance. The result showed that moisture content was reduced from $80 \%$ to $30 \%$ with an average smoking time of 60 mins. The study concluded that fishes smoked by the kiln have a longer shelf life during storage when compared with traditional (drum) method, due to hot smoking temperature which reduces moisture faster. The overall average percentage weight loss obtained for three species tested are as follows: Etholmosa Fimbriata (sawa)-36\%, Scombridae mackerel (37\%) and Clarias gariepinus (cat fish) $-45 \%$.
\end{abstract}

Keywords: Smoking kiln; Motorized; Fish; Charcoal; Temperature; Shelf-life

\section{Introduction}

Fish processing through hot smoking or Kiln is an age long practice in most parts of the world. Nigeria fish smoking practices are yet to gain prominence on a large commercial scale due to lack of appropriate technology approach to assist the fish farming business. Locally available methods such as mud bricks stone and firewood are predominantly used and these affected the quantity and quality of fish processed. Quality control and improved hygienic condition are difficult to sustain while market value diminishes due to damage and non-attractive appearance of the processed fish [1]. Mechanisms used by traditional fish smokers have a lot of limitations. Smoking is a traditional preservation technique used in preparing fish with long storage lives. Smoking contains substances that kill bacterial, thus helping to preserve the product, while the heat dries the fish. In tropical countries, fish are generally heavily smoked at relative high temperature so that they are cooked [2]. In Africa, kiln smoking ranges from traditional open fire to the mud brick, cylindrical drum, and brick [3]. Some of the chemicals in wood smoke will destroy spoilage bacteria and it this effect can be used to advantage in preserving fish. Cooking destroys the action of enzymes and many bacteria because of high temperatures involved [4]. Mechanical smoking kiln was developed and produces high quality fishes with uniform heat distribution. This type uses forced-draft which improves smoking efficiency through appropriate distribution and uses of heat. Mechanical driers are used experimentally and commercially in a number of horizontal flows of air across the product, placed on open-work trays on a trolley [5]. The trolley is pushed into the drying chamber and air passing over is heated by electricity, gas or oil.

Several studies reported the impact of smoking in the fish business and concluded that fish smoking accelerates drying by hastening the water activity and preventing microbial activities as reported by Olayemi et al. [6], Ahmed et al. [7], Ames et al. [1]. The effects of smoke-drying temperatures and duration of drying in the quality of Nile tilapia (Oreochromis nilotisu) has been investigated by Idah and Nwankwo [8] using a modified drum kiln dryer. The authors observed that smoke drying temperature and time influences both nutritive and physical quality of fishes. Tilapia was best smoked at $60^{\circ} \mathrm{C}$ for fish and $70^{\circ} \mathrm{C}$ for 10 hours. Qualities of smoke are enhanced through mixture of hard and soil wood saw draft, while consumption is about $13 \mathrm{~kg}$, for a kiln over $100 \mathrm{~kg}$ capacities. The mixture produces sufficient dense smoke for hot smoking. In hot smoking, temperature remains between $60-119^{\circ} \mathrm{C}$ for $4-12 \mathrm{hrs}$. This is usually long enough to eliminate the growth of spoilage bacteria and helping to preserve the product. The traditional Ghananian mud oven is cylindrical with a thatched cover. The oven consists of layers of mud about $2.5 \mathrm{~m}$ high and $10 \mathrm{~cm}$ thick Grill bars arc installed at about $1 \mathrm{~m}$ off the ground, Fish are smoked on grills within this cylinder. Ivory Coast kiln is efficient and simple with the base of kiln at $2 \times 2 \mathrm{~m}$ and $1 \mathrm{~m}$ high. The sides are sheet metal or corrugated nailed to wooden support posts in the four corners. Fish trays are stacked on top of the oven. In Philippines the smoking chamber is made, of sheet metal and has three doors in the front where trays are inserted. Charcoal is burned in the combustion chamber at the back of the smoker where smoke exits through the chimney [4].

Major local fish processors presently use traditional method accompanied by several limitations. Some of these observed limitations are:

- Poor quality of smoke fish is produced

- Low capacity of quantity of fish processed

- Lot of damages and wastage recorded due to fragmentation

${ }^{*}$ Corresponding author: Ashaolu, Michael O, Agricultural and Bio-Environmental Engineering Department, Lagos State Polytechnic, Ikorodu Lagos, Nigeria, Tel: 08177208446; E-mail: ashaolumike@yahoo.com

Received December 04, 2013; Accepted February 26, 2014; Published March 07,2014

Citation: Ashaolu Michael O (2014) Development and Performance Evaluation of a Motorized Fish Smoking Kiln. J Aquac Res Development 5: 225 doi:10.4172/21559546.1000225

Copyright: (C) 2014 Ashaolu Michael O. This is an open-access article distributed under the terms of the Creative Commons Attribution License, which permits unrestricted use, distribution, and reproduction in any medium, provided the original author and source are credited. 


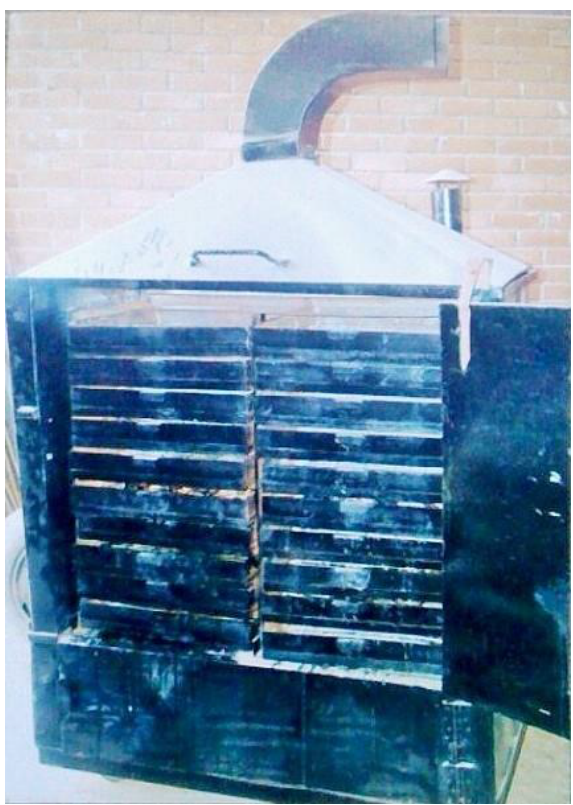

Figure 1: The Fish Smoking kiln.

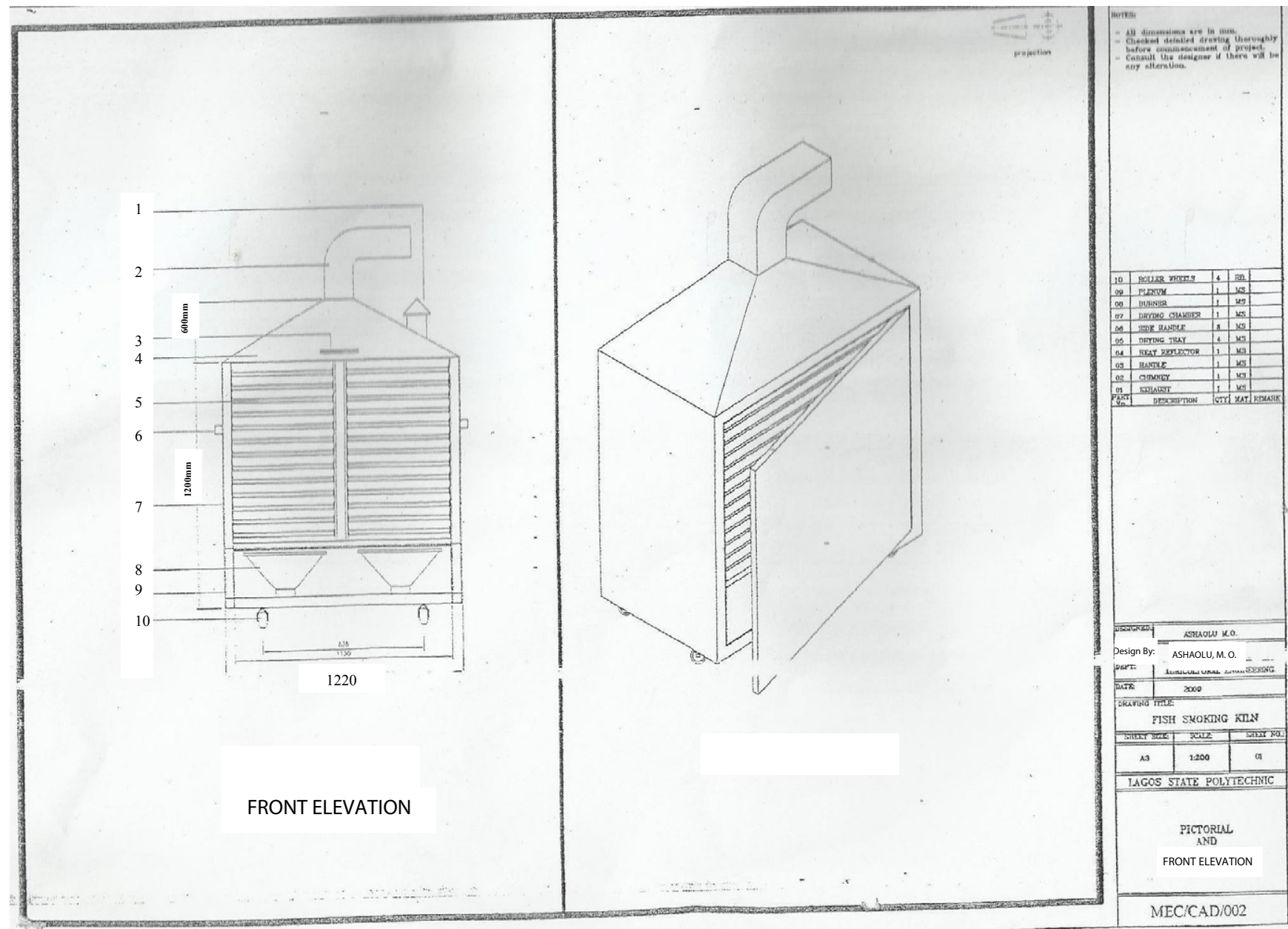

Figure 2: Pictorial and Front Elevation (Smoking Kiln). 


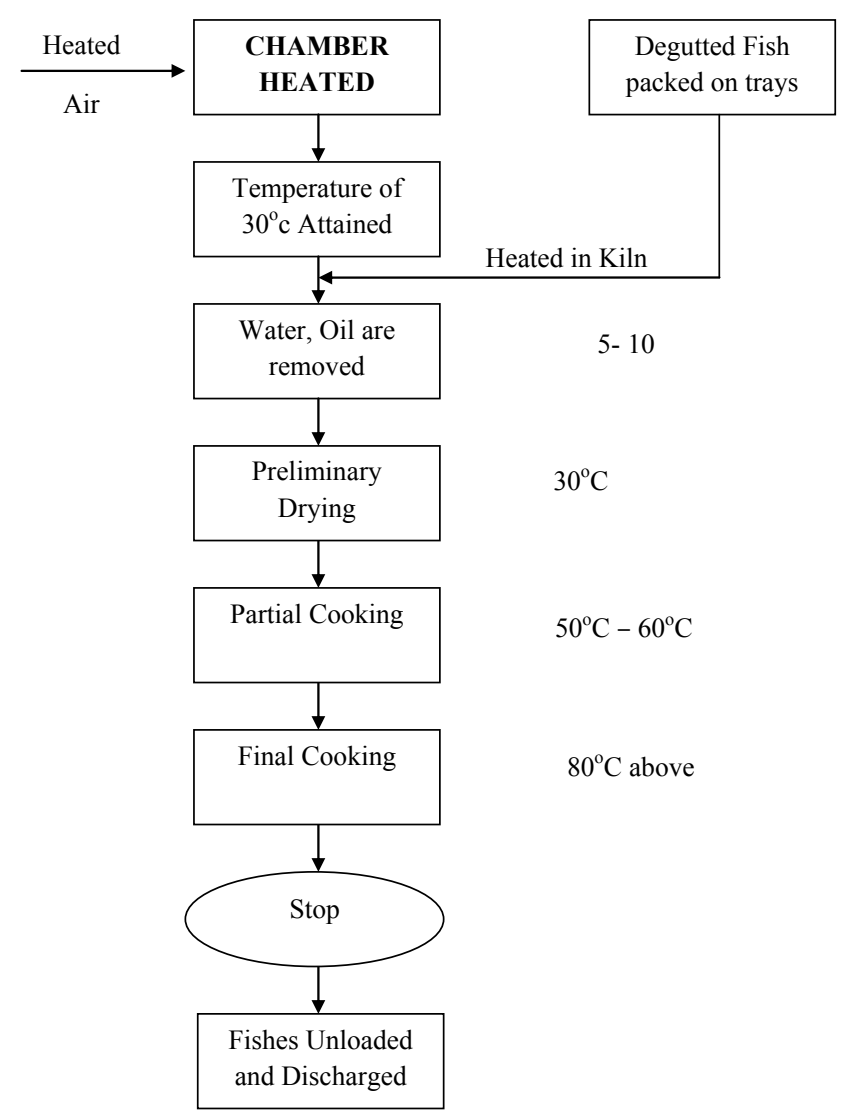

Figure 3: Smoking Process Flow Chart.

- Longer duration of processing

- Most smoking environment is none-hygienic and thus encouraging contaminations and infections.

- Low market value of smoke fish due to unattractive appearance

- Irregular heat distribution and difficulties in regulating smoke.

The objective of this study is to develop a smoking kiln that will address some of this limitations.

\section{Materials and Methods}

\section{Description of the machine}

The developed smoking kiln is shown in Figure 1. The machine was fabricated and assembled at the Engineering workshop of the Department of Agricultural and Bio-Environmental Engineering Lagos State Polytechnic, Ikorodu Lagos, Nigeria. The smoking cabinet is made from galvanized sheet metal and lagged with insulator. The smoking chamber consists of set trays of $520 \times 480 \times 80 \mathrm{~mm}$ arranged into two rows with 10 trays per row. The cabinet overall dimension is 1260 $\mathrm{mm} \times 1220 \times 750 \mathrm{~mm}$. Wire gauze made from stainless steel is placed in each of the trays. The heat source is charcoals which are contained in a pot projected vertically towards the flow of the heated air in the combustion chamber. Air circulation by convection is made possible from the plenum (combustion chamber) and carries heated air in all directions of the loaded trays. A reflector is built in the chimney unit to diffuse the reflected heat back to the smoking chamber. The chimney conducts the smoke to the outdoor environment. Sub units of the smoking kiln include:

1. Smoking chamber

2. Smoking trays

3. Rollers (mobility)

4. Combustion chamber

5. Chimney

6. Reflector

7. Overhead cover

These units are presented in the Pictorial and elevation diagram in Figure 2 .

\section{Experimental Test}

\section{Sample collection and preparation}

The different species of fish were used for the test (Etholmosa Fimbriata(sawa),Scombridae mackerel) and clarias gariepinus (cat fish). The collections were obtained from a fish farm in Ikorodu,Lagos Nigeria. These fishes are the fresh water types commonly found in the locality. The samples were washed and carefully packed for the smoking process. The procedure employed in sequence is as illustrated in Figure 3.

\section{Test methodology}

The motorized smoking kiln was tested and results (Table 1) compared with traditional method (drum smoking) on the basis of output capacity, smoking temperature and time. The following parameters were measured and recorded:

- Smoking temperature

- Output capacity

- Initial and final weight of the smoked fish

- Percentage Weight loss during smoking

The smoking kiln performance was evaluated with samples for each of three species. The smoking temperature is ranges between $60^{\circ} \mathrm{C}$ and $110^{\circ} \mathrm{C}$. The smoking process is based on natural convection. The three species are loaded on the trays at $5 \mathrm{~kg}$ each and the trial run replicated three (3) times. The initial weight and the final weight were recorded. All the fishes were smoked simultaneously and smoking chamber temperatures observed intermittently at $30^{\circ} \mathrm{C}, 60^{\circ} \mathrm{C}, 90^{\circ} \mathrm{C}$, while the time used in smoking the fishes were recorded. The fishes were weighed before the smoking process commenced and after the entire fishes were fully smoked (Appendix1).

\begin{tabular}{|c|c|c|c|c|c|c|}
\hline Species & Trials & $\begin{array}{c}\text { Initial } \\
\text { weight } \\
\text { (kg) }\end{array}$ & $\begin{array}{c}\text { Final } \\
\text { weight } \\
\text { (kg) }\end{array}$ & $\begin{array}{c}\text { \% weight } \\
\text { loss }\end{array}$ & $\begin{array}{c}\text { Smoking } \\
\text { Time(mins) }\end{array}$ & $\begin{array}{c}\text { Fuel } \\
\text { source }\end{array}$ \\
\hline Ethalmosa & 1 & 5 & 3.3 & 34 & & \\
Fimbriata (sawa) & 2 & 5 & 3.2 & 36 & 65 & Charcoal \\
\hline Scombridge & 3 & 5 & 3.2 & 36 & & \\
(mackerel) & 2 & 5 & 3.1 & 38 & & \\
& 3 & 5 & 3.1 & 38 & 60 & Charcoal \\
\hline Clarias gavrepinus & 1 & 5 & 2.8 & 44 & & \\
(catfish) & 2 & 5 & 2.7 & 46 & 45 & Charcoal \\
\hline
\end{tabular}

Table 1: Result of Experimental Test. 


\section{Evaluation of weight loss}

The weight loss during smoking are obtained from the relationship

1. Weight loss = Initial average weight - final average weight (g).....

2. Percentage weight loss $(\%)=\frac{\text { initial weight }- \text { final } w t}{\text { initial weight }} \times 100$

\section{Results and Discussion}

The results of the smoking kiln performance are tabulated and presented in Table 1. The percentage weight losses were also evaluated. The fishes are hot smoked (the temperature of smoke cooks the product). The test results was compared with manual and traditional (local) fish smoking observed that while the developed smoking kiln could smoke $120 \mathrm{~kg}$ in 58 to $75 \mathrm{mins}$, the traditional smoking does only $25 \mathrm{~kg}$ in 3-4 hrs. The fishes were also evenly smoked, except those that are very close to the charcoal fire pot. The average time taken to smoke the entire fishes was 60 mins. This smoking unlike the traditional method preserves the protein content and also retains its texture, flavor and colour. The loss of water was found to be rapid in clarias gariepinus (cat fish) than other fish species resulting in huge weight loss. This is in conformity with other studies that the higher temperature from the heat source, the faster the evaporating process thereby increasing the smoking rate $[9,10]$ and Bolaji [11]. The smoked fish were observed to be firmer when compared to the traditional method. The explanation for this is as a result of regular flow of the heat coupled with rapid intensity as it moves moisture rapidly from the fishes. The heat flow can be controlled through the vent at the opposite sides of the smoking kiln and the shutter which is directly above the charcoal pot.

\section{Conclusion}

In this study, the motorized fish smoking kiln for the riverside local fish farmers was fabricated and performance evaluated for the following fishes ( Etholmosa Fimbriata (sawa), scombridae (mackerel) and clarias gariepinus (cat fish). From the results obtained and the presented discussion, the following conclusions are drawn:

1. Hot smoking reduces the smoking time. The higher the temperature, the faster the drying process.

2. The weight loss through moisture reduction from $80 \%$ moisture content to $30 \%$ moisture content is as a result of increased dehydrating action.

3. The developed smoking kiln produces smoked fish under hygienic condition

4. The smoking temperature regulation was effected through the vent opening and shutters

\section{Further Work}

The study on the developed smoking kiln continues with consideration for the following areas subsequently.

1. Evaluation of the shelf life of the fishes smoked in the kiln.

2. Proximate analysis of the smoked fish.

\section{Acknowledgement}

The author expresses appreciation to the management of Lagos State Polytechnic for the research grant provided to carry out this project

\section{References}

1. Ames G, Clucas I, Paul SS (1999) Post-harvest Losses of Fish in the Tropics. Natural Resources Institute. Overseas Development administration.

2. Eyo AA (2001) Fish Processing Technology in the Tropics. National Institute of Freshwater Fisheries Research. University of Ilorin Press 10-70.

3. Bostock TW, Walker DJ, Wood CD (1987) Tropical Development and Research Institute (Reduction of Losses in Cured fished in the Tropics. Guide for Extension Workers).

4. Clucas IJ (1982) Tropical Development and Research Institute (Fish Handling Preservation and Processing in the Tropic.

5. Clucas IJ, Sutchiffe (1981) An Introduction to Fish Handling and Processing Tropical Products Institute, London.

6. Olayemi FF, Adedayo MR, Bamishaiye El, Awagu EG (2011) Proximate composition of Catfish (clarias gariepinus) smoked in Nigerian Stored Products Research Institute (NSPRI) Developed kiln. Int. Journal of Fisheries and Acquaculture 3: 96 - 98 .

7. Ahmed A, Dodo A, Bouba A, Clement S, Dzudie T (2011) Influence of Traditional Drying and Smoke-drying on the quality of three fish species (Tilapia nilotica, Silurusglanis and Arius parkli) from Lagdo Lake, Cameroon. J Anim Vet Advan 10: $301-306$

8. Idah, Aba P, Nwankwo I (2013) Effects of Smoke-Drying Temperatures and time on Physical and Nutritional Quality Parameters of Tilapia (Oreochroms niloticus). International Journal of Fisheries and Aquaculture 5: 29-34.

9. Khoshmanesh S (2006) Design of Solar Dehydrator, Coupled with Energy Storage in Rock Bed Reservoir for Fish Drying Process. International Conference on energy and Environment (ICEE), Unversiti Tenaga Nasional, Bangi, Selangor, Malaysia.

10. Davies RM, Davies OA (2009) Traditional and Improved Fish Processing Technologies in Bayelsa State, Nigeria. European Journal of Scientific Research 26: $539-548$

11. Bolaji BO (2005) Performance Evaluation of a Simple Solar Dryer for Food preservation. Book of Proceedings of 6th Annual Engineering Technology, Federal University of Technology, Minna, Nigeria. 